\title{
A multiplex PCR assay for the identification of five species of the Anopheles barbirostris complex in Thailand
}

\author{
Laura Brosseau', Chanya Udom², Chutipong Sukkanon ${ }^{3}$, Theeraphap Chareonviriyaphap ${ }^{3}$, Michael J. Bangs ${ }^{3,4}$, \\ Atiporn Saeung ${ }^{5}$ and Sylvie Manguin ${ }^{1 *}$
}

\begin{abstract}
Background: The Barbirostris Complex comprises six formally described species that cannot be differentiated based on morphology alone. Out of these six species, two have been reported as putative malaria vectors, An. campestris and An. wejchoochotei. Five species are present in Thailand, An. barbirostris, An. campestris, An. dissidens, An. saeungae and An. wejchoochotei, while An. vanderwulpi occurs in Indonesia. As these species cannot be accurately differentiated by morphological characters, there is a crucial lack of information on their bionomics and role in the transmission of malaria and filariasis agents.
\end{abstract}

Results: For differentiating the six species, an allele-specific amplification (AS-PCR) based on the second internal transcribed spacer (ITS2) sequence was developed. From 862 mosquitoes in the Barbirostris Complex collected in 23 provinces throughout Thailand, the AS-PCR was able to identify five species and its validation was undertaken on 185 specimens.

Conclusions: This multiplex-PCR assay is potentially able to definitely identify all six species of the Barbirostris Complex and was validated on five species present in Thailand.

Keywords: Anopheles, Barbirostris Complex, ITS2, multiplex PCR, Thailand

\section{Background}

Anopheles (Anopheles) barbirostris belongs to the Barbirostris Complex within the Barbirostris Group of the Myzorhynchus Series [1]. Recently, Taai \& Harbach [2] described within the Barbirostris Complex three new species, An. dissidens, An. saeungae and An. wejchoochotei, which accounts for six formally named species including An. barbirostris, An. vanderwulpi and An. campestris, the latter one being recognized as a member of this complex [2]. Four species are reported as primarily zoophilic throughout their geographic range, although they may bite humans in the absence of their usual hosts (typically bovids). The two others, An. wejchoochotei and An. campestris, are known for their greater anthropophilic

\footnotetext{
*Correspondence: sylvie.manguin@ird.fr

${ }^{1}$ HydroSciences Montpellier (HSM), Institut de Recherche pour le

Développement (IRD), CNRS, Université Montpellier, Montpellier, France

Full list of author information is available at the end of the article
}

behavior, especially the latter species that more readily bites humans than any other members of the Barbirostris Complex [2, 3]. Anopheles barbirostris (s.l.) is widely distributed in Thailand $[4,5]$ and more globally in the Asian region [2, 6-8]. It has been reported as a vector of Plasmodium falciparum and Plasmodium vivax in Sri Lanka, Bangladesh, Indonesia (Sumatra, Sulawesi, Flores), Timor Leste, as well as a secondary vector on the island of Borneo [9] and a putative malaria vector in the Aranyaprathet District, Sa Kaeo Province, southeastern Thailand [10, 11]. More specifically, An. barbirostris (s.l.), An. campestris and An. wejchoochotei (former 'campestris-like', see Table 1) have been incriminated as vectors of $P$. falciparum and P. vivax [2-4, 11-17]. However, the lack of reliable methods to identify the species within the complex has hampered precise evaluation of the specific role of each member in transmission of malaria and other pathogens, e.g. Brugia timori and Brugia malayi in Indonesia $[12,29]$.

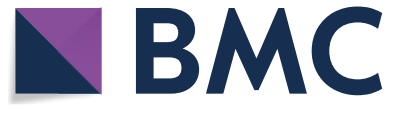

(c) The Author(s) 2019. This article is distributed under the terms of the Creative Commons Attribution 4.0 International License (http://creativecommons.org/licenses/by/4.0/), which permits unrestricted use, distribution, and reproduction in any medium, provided you give appropriate credit to the original author(s) and the source, provide a link to the Creative Commons license, and indicate if changes were made. The Creative Commons Public Domain Dedication waiver (http://creativecommons.org/ publicdomain/zero/1.0/) applies to the data made available in this article, unless otherwise stated. 
Table 1 Correspondence of formally named species in the Barbirostris Complex based on six studies $[23-25,35,36,38]$ and the ITS2 length of the dominant product $[2,24]$, known geographical distribution, biting behavior $[2,8]$ and experimental infection studies $[10$, 17]

\begin{tabular}{|c|c|c|c|c|c|c|c|c|}
\hline \multirow[t]{2}{*}{ Anopheles species } & \multicolumn{4}{|c|}{ Reference } & \multirow[t]{2}{*}{ ITS2 length (bp) } & \multirow[t]{2}{*}{ Confirmed distribution } & \multirow[t]{2}{*}{ Biting behavior } & \multirow[t]{2}{*}{ Experimental infections } \\
\hline & [35] & {$[25,38]$} & [36] & [23] & & & & \\
\hline An. barbirostris & $x$ & - & A4 & Clade 1 & 1637 & $\begin{array}{l}\text { Indonesia, Thailand, } \\
\text { Vietnam }\end{array}$ & Mainly zoophilic & Negative for Pf and Pv \\
\hline An. dissidens & - & $\mathrm{A} 1$ & - & Clade III & 1822 & Thailand & Mainly zoophilic & $\begin{array}{l}\text { Low positivity for } \mathrm{Pv} \\
(9.1 \%)\end{array}$ \\
\hline An. saeungae & - & $\mathrm{A} 2$ & - & Clade IV & 1678 & Indonesia, Thailand & Mainly zoophilic & $\begin{array}{l}\text { Low positivity for } \mathrm{Pv} \\
(6.7 \%)\end{array}$ \\
\hline An. vanderwulpi & W & - & - & Clade II & 1727 & Indonesia & Mainly zoophilic & - \\
\hline An. wejchoochotei & - & An. campestris-like & & Clade V & 1612 & Thailand & Anthropophilic & $\begin{array}{l}\text { High positivity for Pv } \\
(>60 \%)\end{array}$ \\
\hline An. campestris & - & - & - & - & 1519 & Malaysia, Thailand & $\begin{array}{l}\text { Anthropophilic; } \\
\text { malaria vector }\end{array}$ & High positivity for $\mathrm{Pv}$ \\
\hline
\end{tabular}

an. campestris-like (= An. wejchoochotei) originally described by Harrison \& Scanlon [3]

Abbreviations: Pf, Plasmodium falciparum; Pv, Plasmodium vivax

The aim of this study was to develop a rapid and accurate identification method to distinguish the known species of the Barbirostris Complex. The principle of allele-specific PCR (AS-PCR) methodology was selected based on species-specific differences within the sequences of the internal transcribed spacer 2 (ITS2), a ribosomal DNA gene (rDNA) widely used to differentiate cryptic species of Anopheles, particularly those belonging to Asian complexes and groups [18-22].

\section{Methods}

\section{Primer design based on ITS2 sequences}

Allele-specific primers were designed from the rDNA ITS2 sequences from previous studies [2, 23-25]. ITS2 sequences were aligned using Multalin version 5.4.1 [26] to obtain a consensus sequence for each species, which was used to determine specific primers. Primers were designed manually and using the Primer3 input (version 0.4.0) program [27]. The melting temperatures of the primers were kept similar to each other so that they could be combined readily in a single PCR set-up. The oligonucleotide primers were synthetized by Eurogentec (Belgium).

\section{Multiplex allele-specific PCR}

To identify the six species of the Barbirostris Complex, nine primers were designed. To avoid high competition between the primers and according to melting temperatures, a double multiplex PCR was developed. The first PCR (PCR1) was designed to identify An. barbirostris, An. vanderwulpi, An. dissidens and An. campestris, while the second PCR (PCR2) focused on differentiating $A n$. saeungae and An. wejchoochotei. Both PCR1 and PCR2 were carried out using $25 \mu$ l volumes containing 1 unit of GoTaq $^{\circledR}$ G2 Flexi DNA Polymerase, $1 \times$ GoTaq $^{\circledR}$ Flexi
Buffer, $1.5 \mathrm{mM} \mathrm{MgCl}$ (enzyme, buffer and $\mathrm{MgCl}_{2}$ supplied by Promega Corporation, Madison, WI, USA), 200 $\mu \mathrm{M} d \mathrm{NTP}$, each primer at $0.15 \mu \mathrm{M}$ and $0.5 \mu \mathrm{l}$ of extracted DNA. The PCR conditions were carried out at $95^{\circ} \mathrm{C}$ for 1 min, followed by 35 cycles at $95^{\circ} \mathrm{C}$ for $30 \mathrm{~s}, 44^{\circ} \mathrm{C}$ (PCR1) or $51{ }^{\circ} \mathrm{C}$ (PCR2) for $30 \mathrm{~s}$ and $72{ }^{\circ} \mathrm{C}$ for $1 \mathrm{~min}$, with a final extension step at $72{ }^{\circ} \mathrm{C}$ for $10 \mathrm{~min}$. The PCR products were subjected to electrophoresis on a $2 \%$ agarose gel stained with GelRed (Biotium Inc, Fremont, CA, USA).

\section{Mosquito collection, morphological identification and DNA extraction for PCR assay validation}

During December 2016 and March 2017, 862 specimens of the Barbirostris Complex were collected in 23 provinces of Thailand (Fig. 1). Mosquito collections were done between 18:00 and 24:00 h by human-landing catches or cow-baited trapping (tents or landing catches) depending on the locality. Females were individually placed in $1.5 \mathrm{ml}$ Eppendorf tubes and preserved by desiccation with silica gel. Morphological identification of mosquitoes was performed at Kasetsart University using standard illustrated keys allowing the separation of three taxa, An. barbirostris, An. campestris, and a third one called "unknown species" [23]. Genomic DNA was extracted from whole individual adult mosquitoes based on routine procedures [18]. Of 434 samples amplified by AS-PCR, 43 samples were subsequently sequenced for species confirmation and PCR assay validation.

\section{Amplification and sequencing of the ITS2 region}

To confirm the results of the dual multiplex PCR, the ITS2 rDNA of 43 samples with four different profiles were amplified using universal primers ITS2A (5'-TGT GAA CTG CAG GAC ACA T-3') and ITS2B (5'-TAT GCT TAA ATT CAG GGG GT-3') $[25,28]$. Reactions were 


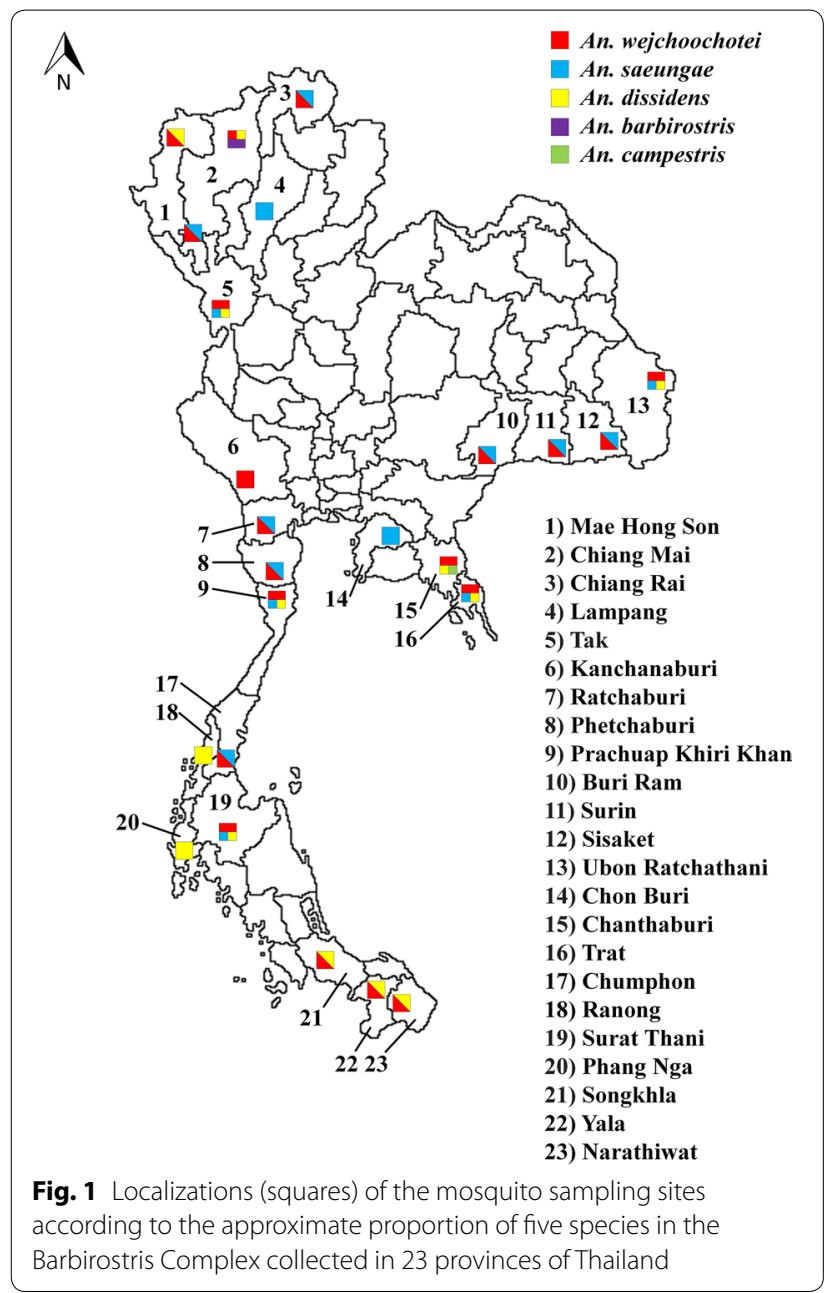

performed in a $50 \mu \mathrm{l}$ volume using a "ProFlex" thermal cycler (Thermo Fisher Scientific, Waltham, MA, USA). Each tube contained $1 \mu \mathrm{l}$ of mosquito DNA from the previous extractions, each primer at $0.2 \mu \mathrm{M}, 200 \mu \mathrm{M} d \mathrm{NTP}$,
$1.5 \mathrm{mM} \mathrm{MgCl} 2,1 \times \mathrm{GoTaq}^{\circledR}$ Flexi Buffer and 2 units of GoTaq $^{\circledR}$ G2 Flexi DNA Polymerase (enzyme, buffer and $\mathrm{MgCl}_{2}$ supplied by Promega Corporation, Madison, WI, USA). The amplification was done at $95^{\circ} \mathrm{C}$ for $1 \mathrm{~min}$, followed by 35 cycles of amplification at $95^{\circ} \mathrm{C}$ for $30 \mathrm{~s}, 51^{\circ} \mathrm{C}$ for $30 \mathrm{~s}$ and $72{ }^{\circ} \mathrm{C}$ for $1 \mathrm{~min}$, with a final extension step at $72{ }^{\circ} \mathrm{C}$ for $10 \mathrm{~min}$. The amplification products were sequenced by Genewiz ${ }^{\circledR}$ Society (Paris, France).

\section{Results}

\section{Primer design}

Primer design was based on the ITS2 sequences of five out of six species available in GenBank (Table 2); the ITS2 sequence of An. campestris is not available. Primer names, sequences, size of the PCR products and respective melting temperatures $(\mathrm{Tm})$ are presented in Table 3. Due to the close similarity of the ITS2 sequences of the six members, primer design was difficult with some species having similar individual size bands (bp), thus a dual PCR assay was developed in order to more reliably separate all species. Based on nucleotide alignment of the ITS2 region, nine primers were designed. A forward primer common to five species, except An. campestris (fBDSVW), then two species-specific forward primers (fBar, fCamp), and six reverse primers (rBar\&Van, rVan\&Dis, rCamp, rSaue1, rSaue2, rWej). Anopheles barbirostris is interrogated by two forward primers (fBDSVW and fBar) and one reverse primer (rBar\&Van) providing 2 bands at 388 bp and 208 bp in PCR1 (Table 3). It was necessary to design a speciesspecific forward primer (fBar) for An. barbirostris in order to differentiate it from $A n$. vanderwulpi, which shares the same two other primers (fBDSVW and rBar\&Van). Nucleotide alignment of the amplified ITS2 region for the six species and the nine primer sites are shown in Fig. 2. The specificity of each primer was tested and the results presented in Fig. 3.

Table 2 Provenance of samples, GenBank accession numbers, and sources of the ITS2 sequences specific of 5 species of the Barbirostris Complex used for primer design (source: Table S1 in [2])

\begin{tabular}{|c|c|c|c|}
\hline Anopheles species & Provenance of samples & GenBank ID & Reference \\
\hline \multirow{3}{*}{$\begin{array}{l}\text { An. barbirostris } \\
(n=3)\end{array}$} & Chiang Mai, Thailand & AB971283.1 & {$[2]$} \\
\hline & Mae Hong Son, Thailand & EU812764.1 & {$[23]$} \\
\hline & South Kalimantan, Indonesia & EU812759.1 & {$[23]$} \\
\hline $\begin{array}{l}\text { An. dissidens } \\
(n=13)\end{array}$ & Chiang Mai, Thailand & AB971284.1-AB971296.1 & {$[2]$} \\
\hline \multirow{3}{*}{$\begin{array}{l}\text { An. saeungae } \\
(n=9)\end{array}$} & Lampang, Thailand & AB971297.1-AB971305.1 & {$[2]$} \\
\hline & Trat, Thailand & EU812795.1 & {$[23]$} \\
\hline & West Sumatra, Indonesia & EU812791.1 & {$[23]$} \\
\hline $\begin{array}{l}\text { An. vanderwulpi } \\
(n=3)\end{array}$ & West Sumatra, Indonesia & EU812766.1-EU812768.1 & {$[23]$} \\
\hline \multirow{2}{*}{$\begin{array}{l}\text { An. wejchoochotei } \\
(n=8)\end{array}$} & Chiang Mai, Thailand & AB971306.1-AB971311.1 & {$[2]$} \\
\hline & Sa Kaeo, Thailand & EU812808.1-EU812809.1 & {$[23]$} \\
\hline
\end{tabular}


Table 3 Information on the nine primers designed for the dual multiplex PCR assay (PCR1, PCR2) for the identification of the six species of the Barbirostris Complex

\begin{tabular}{|c|c|c|c|c|c|c|}
\hline Primer name & Specificity & Sequence $\left(5^{\prime}-3^{\prime}\right)$ & CG \% & $\operatorname{Tm}\left({ }^{\circ} \mathrm{C}\right)$ & Product size (bp) & PCR assay \\
\hline fBDSVW & Common to 5 species & CGGATCGCATTATGTTGAAGG & 47.6 & 47.3 & & 1,2 \\
\hline fBar & An. barbirostris & CTGTTACACACGGTCCAAAAG & 47.6 & 47.3 & 208 & 1 \\
\hline fCamp & An. campestris & GTTAGAAAATGGCAACATGAGCAA & 37.5 & 47.2 & & 1 \\
\hline rBar\&Van & $\begin{array}{l}\text { An. barbirostris; } \\
\text { An. vanderwulpi }\end{array}$ & ATGCTTAAATTTAGGGGGTAGTC & 40.0 & 49.3 & $\begin{array}{l}388 \\
401\end{array}$ & 1 \\
\hline rVan\&Dis & $\begin{array}{l}\text { An. vanderwulpi; } \\
\text { An. dissidens }\end{array}$ & CCCGAAAAAGAAGATGGTGAACA & 43.5 & 48.4 & $\begin{array}{l}141 ; \\
141\end{array}$ & 1 \\
\hline rCamp & An. campestris & CTCCACAAATTTCAGAACATTGTCC & 40.0 & 49.3 & 612 & 1 \\
\hline rSaeu1 & An. saeungae & CACTAAGCGAGAGCTTCCA & 52.6 & 58 & 294 & 2 \\
\hline rSaeu2 & An. saeungae & TTCGCAAACCTATCGACTCC & 50.0 & 60 & 378 & 2 \\
\hline rWej & An. wejchoochotei & GGGTGTGTGCTGGAGAAA & 55.6 & 56 & 245 & 2 \\
\hline
\end{tabular}

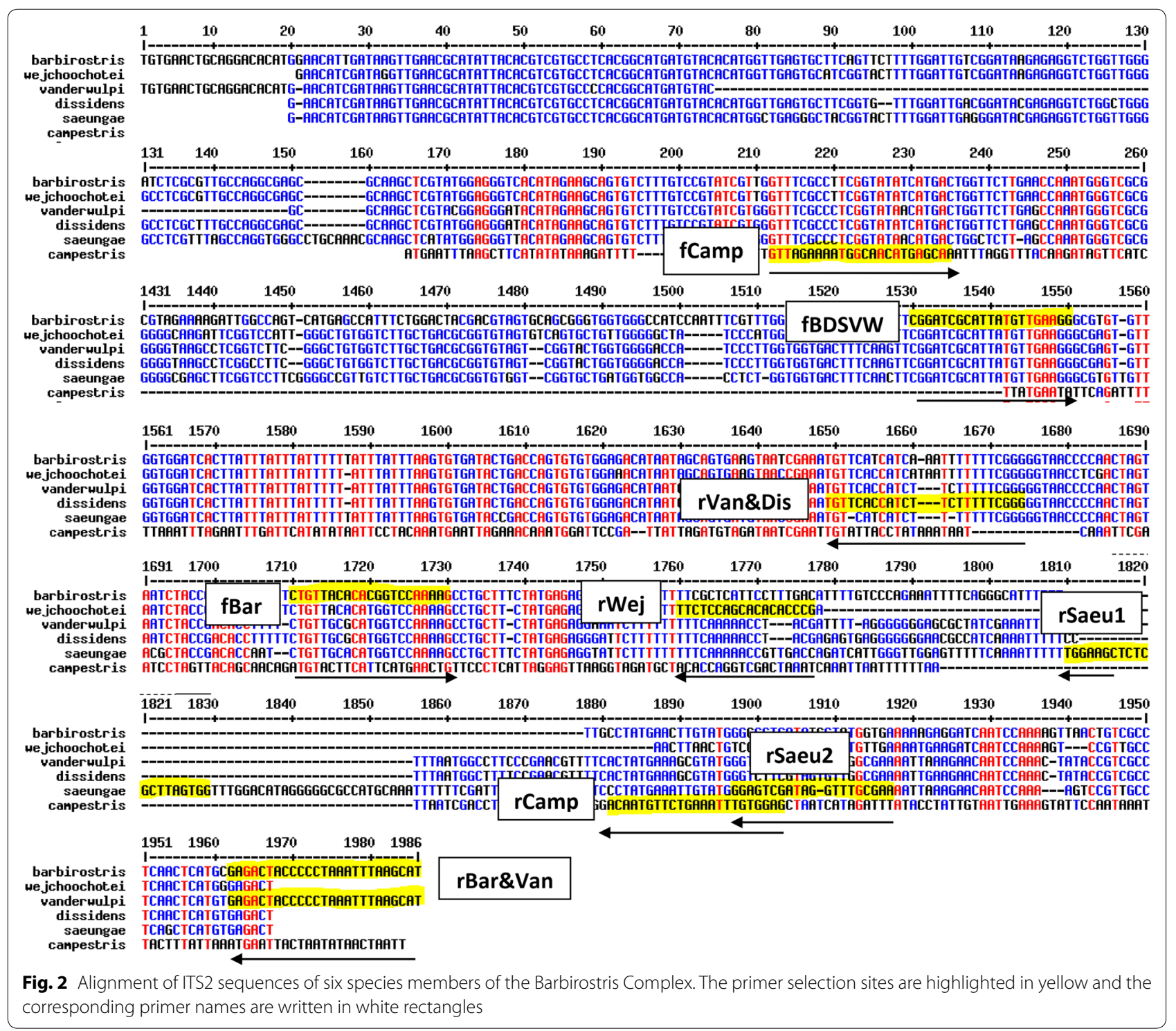



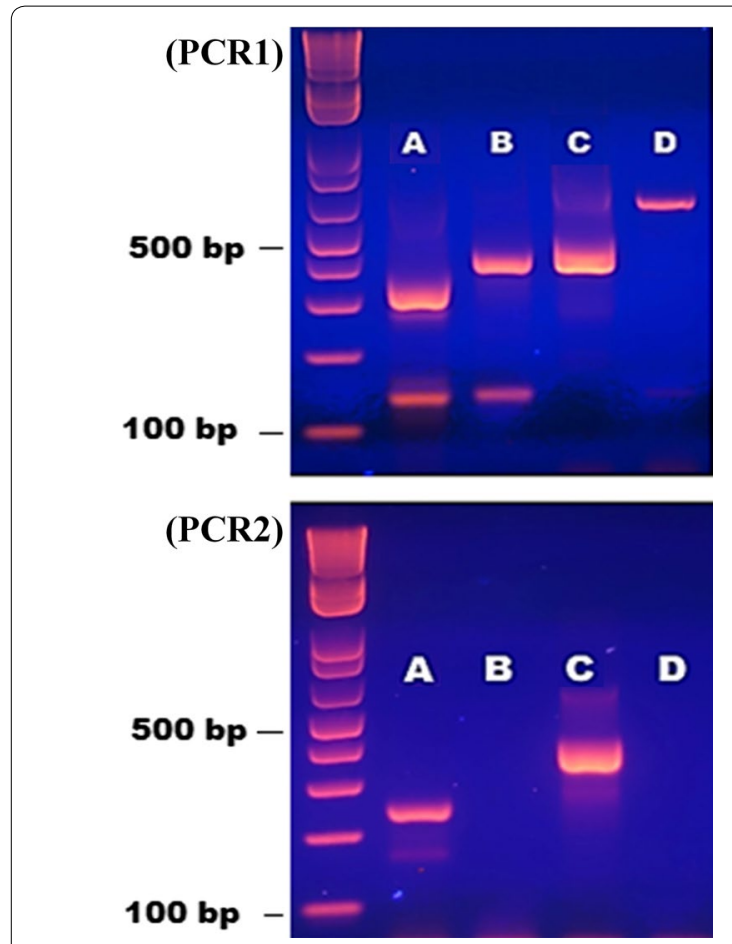

Fig. 3 Multiplex PCR products from PCR1 (top gel) and PCR2 (bottom gel) of species of the Barbirostris Complex run on 2\% agarose gel. For PCR 1 and 2, Lane A: An. wejchoochotei; Lane B: An. dissidens; Lane C: An. saeungae; Lane D: An. campestris. The fragment sizes of the DNA ladder are indicated in base pairs (bp)

\section{Multiplex PCR}

The three forward primers and the six reverse primers in the two PCR assays were able to differentiate simultaneously at least five members of the Barbirostris Complex. In PCR1, An. barbirostris and An. dissidens showed two bands: at 388 bp and 208 bp for An. barbirostris and at $410 \mathrm{bp}$ and $141 \mathrm{bp}$ for An. dissidens (Tables 3, 4, Figs. 3, 4). Anopheles saeungae presented two distinct bands, at $420 \mathrm{bp}$ in PCR1 and another at $378 \mathrm{bp}$ in PCR2; while An. wejchoochotei displayed three bands, at $335 \mathrm{bp}$ and $141 \mathrm{bp}$ in PCR1

Table 4 Amplified fragment sizes in basepairs (bp) obtained for PCR1 and PCR 2 (when applicable) for five species of the Barbirostris Complex from Thailand

\begin{tabular}{lll}
\hline Species & PCR 1 (bp) & PCR 2 (bp) \\
\hline Anopheles barbirostris & $388 ; 208$ & - \\
Anopheles campestris & 612 & - \\
Anopheles dissidens & $410 ; 141$ & - \\
Anopheles saeungae & 420 & 378 \\
Anopheles wejchoochotei & $335 ; 141$ & 245 \\
\hline
\end{tabular}

and at 245 bp in PCR2 (Tables 3, 4, Figs. 3, 4). The purpose of developing a dual PCR, incorporating PCR2, was to confirm the differentiation between An. saeungae and An. dissidens, which have similar band sizes respectively at $420 \mathrm{bp}$ and $410 \mathrm{bp}$ in PCR1, while the second band at $141 \mathrm{bp}$ present for An. dissidens may not always be visible. When all five species showed their respective band(s) in PCR1 (Table 4, Figs. 3, 4), there was no need for PCR2. Lastly, An. campestris was represented by a single band at 612 bp in PCR1. Primers have been designed for An. vanderwulpi but as this species is absent from Thailand, no specimen was tested. Most of the expected band sizes by species listed in Table 3 were confirmed in the AS-PCR (Table 4).

\section{Sequencing of the ITS2 region}

The complete ITS2 sequence length of each species ranges between 1500-1850 bp (Table 1). Within the 43 sequenced samples, three profiles were obtained from 31 specimens that matched the ITS2 sequences of $A n$. wejchoochotei $(n=14)$, An. saeungae $(n=10)$ and $A n$. dissidens $(n=7)$, respectively (Table 5$)$. For the 12 additional sequences, a small part of the ITS2 sequence was amplified, which could not allow any definitive species identification.

\section{Distribution of the Barbirostris Complex species in Thailand}

Anopheles wejchoochotei was identified in $54.6 \%$ of the specimens and in 19 of 23 sampled provinces indicating a wide distribution in Thailand (Fig. 1, Table 6). The second most common species was An. saeungae with $18.9 \%$ of the specimens collected in 15 provinces located throughout Thailand, excluding the southernmost region. Anopheles dissidens was found in 13 provinces, representing $24.3 \%$ of the collected specimens that were mainly located in the western and southern areas of Thailand. Anopheles barbirostris, with only $1.6 \%$ of the specimens identified, appeared confined to Chiang Mai Province, northern Thailand; while only one specimen (0.5\%) of $A n$. campestris was collected in Chanthaburi Province, eastcentral Thailand.

\section{Discussion}

Populations of An. barbirostris (s.l.) have been identified across a wide geographic range including India and Sri Lanka, throughout most of Southeast Asia, in particular Malaysia and Indonesia where it extends from Sumatra, Java, Bali in the west, to Kalimantan, Sulawesi, and throughout the Lesser Sunda Islands and TimorLeste in the east [7]. Their role in transmission of both malaria and Brugian filariasis has been documented in 


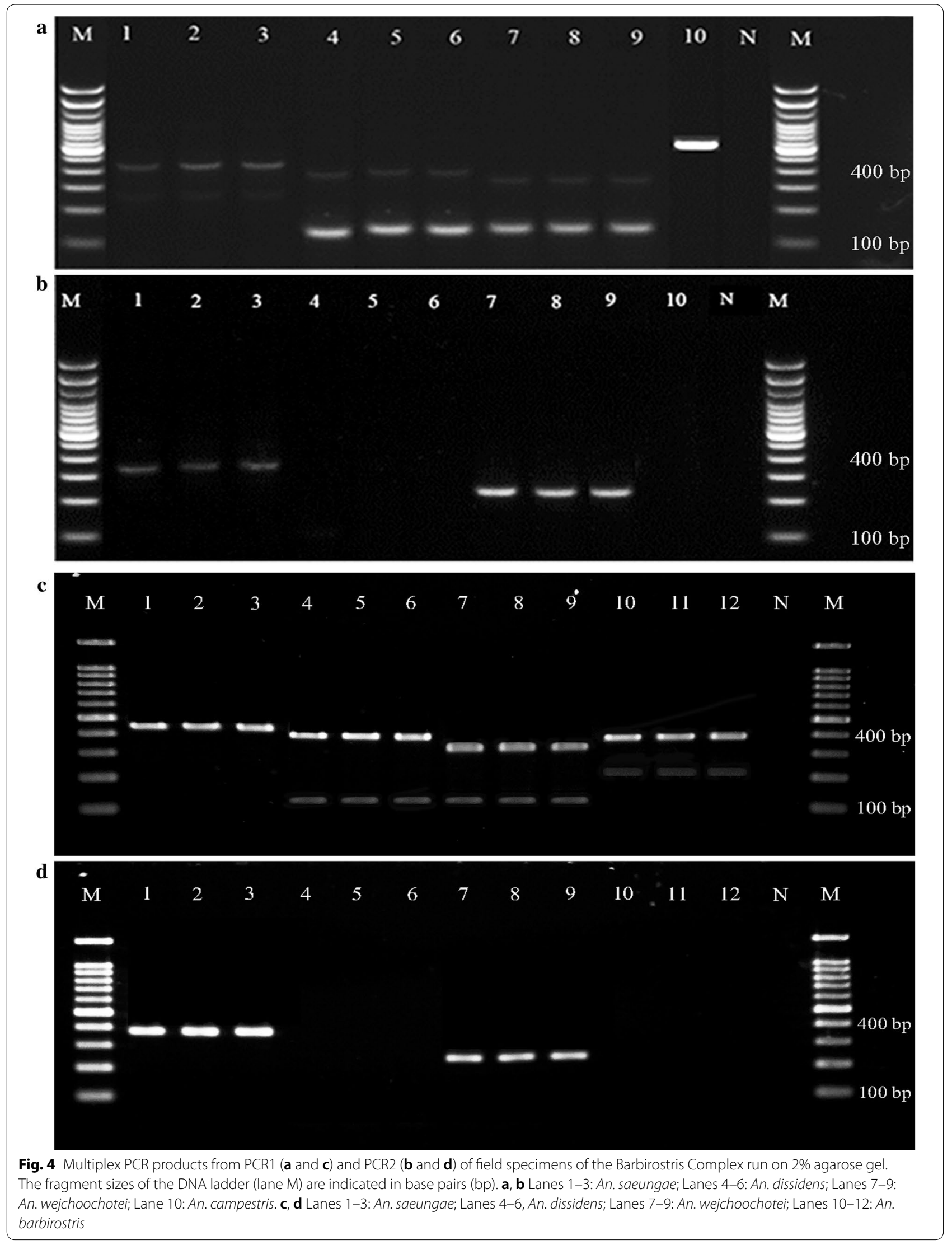


Table 5 ITS2 sequences and corresponding GenBank accession numbers of 31 specimens belonging to three species of the Barbirostris Complex collected from 12 provinces in Thailand

\begin{tabular}{|c|c|c|c|c|}
\hline Species & Province $^{a}$ & Province code & No. of isoline & Genbank ID \\
\hline \multirow{9}{*}{$\begin{array}{l}\text { An. wejchoochotei } \\
(n=14)\end{array}$} & Chanthaburi (12) & $\mathrm{CHN}$ & 2 & MH796402, MH796403 \\
\hline & Kanchanaburi (5) & KAN & 1 & MH796405 \\
\hline & Prachuap Khiri Khan (8) & PRA & 1 & MH796406 \\
\hline & Ratchaburi (6) & RAT & 1 & MH796407 \\
\hline & Sisaket (9) & SRI & 1 & MH796408 \\
\hline & Surat Thani (14) & SUR & 1 & MH796409 \\
\hline & Tak (4) & TAK & 1 & MH796410 \\
\hline & Trat (13) & TRA & 3 & MH796411, MH796412, MH796413 \\
\hline & Ubon Ratchathani (10) & UBO & 3 & MH796414, MH796415, MH796416 \\
\hline \multirow{6}{*}{$\begin{array}{l}\text { An. saeungae } \\
(n=10)\end{array}$} & Chon Buri (11) & CBN & 3 & MH796417, MH796418, MH796419 \\
\hline & Phetchaburi (7) & PHT & 1 & MH796420 \\
\hline & Prachuap Khiri Khan (8) & PRA & 2 & MH796421, MH796422 \\
\hline & Ratchaburi (6) & RAT & 1 & MH796423 \\
\hline & Surat Thani (14) & SUR & 2 & MH796424, MH796425 \\
\hline & Tak (4) & TAK & 1 & MH796426 \\
\hline \multirow{5}{*}{$\begin{array}{l}\text { An. dissidens } \\
(n=7)\end{array}$} & Mae Hong Son (1) & MAE & 1 & MH796437 \\
\hline & Prachuap Khiri Khan (8) & PRA & 2 & MH796438, MH796439 \\
\hline & Surat Thani (14) & SUR & 2 & MH796440, MH796441 \\
\hline & Tak (4) & TAK & 1 & MH796442 \\
\hline & Ubon Ratchathani (10) & UBO & 1 & MH796443 \\
\hline
\end{tabular}

${ }^{a}$ Number according to Fig. 1

Sulawesi, Flores and Timor [12, 13, 29-32], and mentioned as putative malaria vectors in Sri Lanka [33], possibly Bangladesh [34] and Thailand [10, 11, 17]. However, all of these reports on the natural vectorial role of $A n$. barbirostris (s.l.) are based on unreliable morphological identifications and a period before the Barbirostris Complex was recognized in 2001 [35]. The complex now includes six formally named sibling species [1], and while almost identical (isomorphic) in adult morphology, their respective roles in malaria and filarial transmission differs drastically (Table 1). In Thailand, five formal species have been identified, while a sixth one, An. barbirostris species A3, has been reported from Kanchanaburi Province $[25,36]$. Not formally characterized and unnamed, this species has a much smaller ITS2 sequence of 1070 bp [25]. Due to the lack of specimens, species A3 has not been included in this study, although primers have been designed to differentiate it from the other species of the complex. Considering the wide geographical distribution of the Barbirostris Complex and the involvement of some members in plasmodia and filarial transmission, it is crucial to better understand the full diversity of species that constitute the complex and which ones are vectors of public health importance so as to better target control efforts to maximize suppression of transmission and increase the likelihood of achieving malaria elimination [37]. Therefore, a reliable identification technique using molecular methods was an essential development to differentiate between species, especially those that occur in sympatry, that would allow further investigation on their specific bionomics, distribution and role in pathogen transmission.

For correct identification at the species level, molecular markers are used to separate sibling species, especially the rRNA ITS2 gene that is widely used to differentiate within many Asian Anopheles complexes [18-22]. The developed AS-PCR was able to differentiate all five species of the Barbirostris Complex present in Thailand. Primers to identify the species occurring in Indonesia, $A n$. vanderwulpi, also found in sympatry with $A n$. barbirostris [8], and An. barbirostris species A3 from Thailand have been designed and awaiting validation analysis of field samples when available. The application of this AS-PCR assay on 185 specimens collected throughout Thailand showed the wide distribution of $A n$. wejchoochotei, previously presented as An. campestris-like species in a published distribution map [5]. This species is often found in sympatry with An. saeungae and An. dissidens based on collections from 13 and 11 provinces, respectively. Anopheles barbirostris, collected in one site 
Table 6 Molecular identification of 185 field specimens of the Barbirostris Complex from 23 provinces of Thailand using the multiplex PCR assay developed in this study

\begin{tabular}{|c|c|c|c|c|c|c|c|}
\hline \multicolumn{3}{|l|}{ Collection sites } & \multicolumn{5}{|c|}{ Number of specimens } \\
\hline Region & Province $^{a}$ & District & wej & saeu & diss & barb & camp \\
\hline \multirow[t]{5}{*}{ Northern } & Mae Hong Son (1) & Khun Yuam & 4 & & 4 & & \\
\hline & Chiang Mai (2) & Chiang Dao & 3 & & 3 & 3 & \\
\hline & & Omkoi & 5 & 4 & & & \\
\hline & Chiang Rai (3) & Mae Sai & 4 & 3 & & & \\
\hline & Lampang (4) & Ko Kha & & 3 & & & \\
\hline \multirow[t]{5}{*}{ Western } & Tak (5) & Mae Ramat & 4 & 1 & 1 & & \\
\hline & Kanchanaburi (6) & Sai Yok & 6 & & & & \\
\hline & Ratchaburi (7) & PakTho & 6 & 1 & & & \\
\hline & Phetchaburi (8) & Ta Yang & 5 & 1 & & & \\
\hline & Prachuap Khiri Khan (9) & Huahin & 6 & 4 & 5 & & \\
\hline \multirow[t]{4}{*}{ Northeastern } & Buri Ram (10) & Lahan Sai & 5 & 2 & & & \\
\hline & Surin (11) & Si Narong & 5 & 2 & & & \\
\hline & Sisaket (12) & Phu Sing & 6 & 1 & & & \\
\hline & Ubon Ratchathani (13) & Si Mueang Mai & 8 & 1 & 1 & & \\
\hline \multirow[t]{3}{*}{ Eastern } & Chon Buri (14) & & & 3 & & & \\
\hline & Chanthaburi (15) & Makham & 7 & & 5 & & 1 \\
\hline & Trat (16) & Borai & 8 & 2 & 3 & & \\
\hline \multirow[t]{7}{*}{ Southern } & Chumphon (17) & Pato & 5 & 5 & & & \\
\hline & Ranong (18) & La-un & & & 2 & & \\
\hline & Surat Thani (19) & Panom & 6 & 2 & 6 & & \\
\hline & Phang Nga (20) & Thai Mueang & & & 2 & & \\
\hline & Songkhla (21) & Sadao & 3 & & 5 & & \\
\hline & Yala (22) & Bannang Sata & 3 & & 5 & & \\
\hline & Narathiwat (23) & Rueso & 2 & & 3 & & \\
\hline Total $(n=185)$ & & & 101 & 35 & 45 & 3 & 1 \\
\hline Frequency (\%) & & & 54.6 & 18.9 & 24.3 & 1.6 & 0.5 \\
\hline
\end{tabular}

${ }^{a}$ Number according to Fig. 1

Abbreviations: wej: An. wejchoochotei; saeu: An. saeungae; diss: An. dissidens; barb: An. barbirostris; camp: An. campestris

only in Chiang Mai Province, was sympatric with both An. wejchoochotei and An. dissidens, while An. saeungae was the only species collected in Lampang (northern) and Chon Buri (eastern) Provinces. Only one specimen of Anopheles campestris, regarded an important vector of malaria and Brugia malayi filariasis [4], was collected in Chanthaburi Province, eastern Thailand.

\section{Conclusions}

This study provides a simple, rapid, specific and efficient multiplex PCR assay for identifying the six described species members of the Barbirostris Complex. This assay has been validated on five species present in Thailand. Specimens of An. vanderwulpi from Indonesia and An. barbirostris species A3 from Thailand should now be tested using this AS-PCR in order to validate the primers. This multiplex PCR is a reliable identification tool for allowing a wide range of studies on the known species of the Barbirostris Complex. The assay also provides a tool with the possibility of recognition of new cryptic species populations throughout the broader geographical range of this complex.

\section{Acknowledgements}

The authors would like to thank the people in the study areas of Thailand for cooperating during the mosquito collections.

\section{Authors' contributions}

SM conceived the work. LB designed and performed the experiments. LB and SM analyzed the data and wrote the manuscript. CU, CS and AS collected field specimens and validated the PCR assay. CS, TC, MJB, AS revised and improved the manuscript. All authors read and approved the final manuscript.

\section{Funding}

The study activities were funded by both the research budget of the IRD laboratory of Montpellier, France and the Foreign Exchange Program for Graduate Students, Center for Advanced Studies for Agriculture and Food (CASAF), Kasetsart University Institute for Advanced Studies, Kasetsart University and International Research Network, Thailand Research Fund (IRN 58W0003), Thailand. 


\section{Availability of data and materials}

The datasets supporting the conclusions of this article are included within the article. The raw data used are available from the corresponding author upon reasonable request. Sequences are deposited in GenBank database under the accession numbers MH796402-MH796426 and MH796437-MH796443.

\section{Ethics approval and consent to participate}

Ethics approval was given by the Research Ethics Review committee for research involving human research participants, Health Sciences Group, Chulalongkorn University, Bangkok, Thailand (Certificate of approval No. 089/2017)

\section{Consent for publication}

Not applicable.

\section{Competing interests}

The authors declare that they have no competing interests.

\section{Author details}

${ }^{1}$ HydroSciences Montpellier (HSM), Institut de Recherche pour le Développement (IRD), CNRS, Université Montpellier, Montpellier, France. ${ }^{2}$ Department of Zoology, Faculty of Science, Kasetsart University, Bangkok 10900, Thailand. ${ }^{3}$ Department of Entomology, Faculty of Agriculture, Kasetsart University, Bangkok 10900, Thailand. ${ }^{4}$ Department of Public Health and Malaria Control, International SOS, Jl. Kertajasa, Kuala Kencana, Papua 99920, Indonesia.

${ }^{5}$ Department of Parasitology, Faculty of Medicine, Chiang Mai University, Chiang Mai 50200, Thailand.

Received: 20 February 2019 Accepted: 6 May 2019 Published online: 14 May 2019

\section{References}

1. Harbach RE. Anopheles classification. Mosquito taxonomic inventory. http://www.mosquito-taxonomic-inventory.info/. 2018 (updated on 04/12/2018). Accessed 17 Jan 2019.

2. Taai K, Harbach RE. Systematics of the Anopheles barbirostris species complex (Diptera: Culicidae: Anophelinae) in Thailand. Zool J Linn Soc. 2015;174:244-64.

3. Harrison BA, Scanlon JE. Medical entomology studies-II. The subgenus Anopheles in Thailand (Diptera: Culicidae). Contrib Am Entomol Inst (Ann Arbor). 1975;12:1-307.

4. Rattanarithikul R, Harrison BA, Harbach RE, Panthusiri P, Coleman RE, Panthusiri P. Illustrated keys to the mosquitoes of Thailand. IV. Anopheles. Southeast Asian J Trop Med Public Health. 2006;37(Suppl. 2):1-128.

5. Tainchum K, Kongmee M, Manguin S, Bangs MJ, Chareonviriyaphap T. Anopheles species diversity and distribution of the malaria vectors of Thailand. Trends Parasitol. 2015;31:109-19.

6. Scanlon JE, Peyton EL, Gould DJ. An annotated checklist of the Anopheles of Thailand (Diptera: Culicidae). In: Thai National Science Papers, Fauna Series, Bangkok: Applied Science Research Corporation of Thailand, 1968. Vol. 2, p. 1-35.

7. Sinka ME, Bangs MJ, Manguin S, Chareonviriyaphap T, Patil AP, Temperley WH, et al. The dominant Anopheles vectors of human malaria in the AsiaPacific region: occurrence data, distribution maps and bionomic precis. Parasit Vectors. 2011:4:89.

8. Townson H, Dyer N, McAlister E, Satoto TBT, Bangs MJ, Harbach RE. Systematics of Anopheles barbirostris Van der Wulp and a sibling species of the Barbirostris Complex (Diptera: Culicidae) in easter Java, Indonesia. Syst Entomol. 2013:38:180-91.

9. De Zulueta J, Lachance F. A malaria-control experiment in the interior of Borneo. Bull World Health Organ. 1956;15:673-93.

10. Apiwathnasor C, Prommongkol S, Samung Y, Limrat D, Rojruthai B. Potential for Anopheles campestris (Diptera: Culicidae) to transmit malaria parasites in Pa Rai subdistrict (Aranyaprathet, Sa Kaeo Province), Thailand. J Med Entomol. 2002;39:583-6.

11. Limrat D, Rojruthai B, Apiwathnasorn C, Samung Y, Prommongkol S. Anopheles barbirostris/campestris as a probable vector of malaria in
Aranyaprathet, Sa Kaeo Province. Southeast Asian J Trop Med Public Health. 2001;32:739-44.

12. Atmosoedjono S, Partono F, Dennis DT. Anopheles barbirostris (Diptera: Culicidae) as a vector of the timor filaria on Flores Island: preliminary observations. J Med Entomol. 1977;13:611-3.

13. Cooper RD, Edstein MD, Frances SP, Beebe NW. Malaria vectors of TimorLeste. Malar J. 2010:9:40.

14. De Zulueta J. Malaria in Sarawak and Brunei. Bull World Health Organ. 1956;15:651-71.

15. Poolphol P, Harbach RE, Sriwichai P, Aupalee K, Sattabongkot J, Kumpitak $C$, et al. Natural Plasmodium vivax infections in Anopheles mosquitoes in a malaria endemic area of northeastern Thailand. Parasitol Res. 2017;116:3349-59.

16. Sriwichai P. Potential Plasmodium vivax malaria vector of Anopheles campestris in focal endemic area along Thai-Cambodia border. In: 14th Young Researcher Meet Senior Scholar of Thailand Research Fund Organization. Bangkok: Thai Research Fund Organization; 2014. p. 170.

17. Thongsahuan S, Baimai V, Junkum A, Saeung A, Min GS, Joshi D, et al. Susceptibility of Anopheles campestris-like and Anopheles barbirostris species complexes to Plasmodium falciparum and Plasmodium vivax in Thailand. Mem Inst Oswaldo Cruz. 2011;106:105-12.

18. Garros C, Koekemoer LL, Coetzee M, Coosemans M, Manguin S. A single multiplex assay to identify major malaria vectors within the African Anopheles funestus and the Oriental An. minimus groups. Am J Trop Med Hyg. 2004;70:583-90

19. Hempolchom C, Otsuka Y, Baimai V, Thongsahuan S, Saeung A, Taai K, et al. Development of a multiplex PCR assay for the identification of eight species members of the Thai Hyrcanus Group (Diptera: Culicidae). Appl Entomol Zool. 2013:48:469-76.

20. Walton C, Handley JM, Kuvangkadilok C, Collins FH, Harbach RE, Baimai $V$, et al. Identification of five species of the Anopheles dirus complex from Thailand, using allele-specific polymerase chain reaction. Med Vet Entomol. 1999;13:24-32.

21. Walton C, Somboon P, O'Loughlin SM, Zhang S, Harbach RE, Linton YM, et al. Genetic diversity and molecular identification of mosquito species in the Anopheles maculatus group using the ITS2 region of rDNA. Infect Genet Evol. 2007;7:93-102.

22. Manonmani A, Townson H, Adeniran T, Jambulingam P, Sahu S, Vijayakumar T. rDNA-ITS2 polymerase chain reaction assay for the sibling species of Anopheles fluviatilis. Acta Trop. 2001;78:3-9.

23. Paredes-Esquivel C, Donnelly MJ, Harbach RE, Townson H. A molecular phylogeny of mosquitoes in the Anopheles barbirostris Subgroup reveals cryptic species: implications for identification of disease vectors. Mol Phylogenet Evol. 2009;50:141-51.

24. Paredes-Esquivel CC, Townson $\mathrm{H}$. Functional constraints and evolutionary dynamics of the repeats in the rDNA internal transcribed spacer 2 of members of the Anopheles barbirostris group. Parasit Vectors. 2014;7:106.

25. Saeung A, Baimai V, Otsuka Y, Rattanarithikul R, Somboon P, Junkum A, et al. Molecular and cytogenetic evidence of three sibling species of the Anopheles barbirostris Form A (Diptera: Culicidae) in Thailand. Parasitol Res. 2008;102:499-507.

26. Corpet F. Multiple sequence alignment with hierarchical clustering Nucleic Acids Res. 1988;16:10881-90.

27. Rozen S, Skaletsky H. Primer3 on the WWW for general users and for biologist programmers. Methods Mol Biol. 2000;132:365-86.

28. Beebe NW, Saul A. Discrimination of all members of the Anopheles punctulatus complex by polymerase chain reaction-restriction fragment length polymorphism analysis. Am J Trop Med Hyg. 1995;53:478-81.

29. Atomosoedjono S, Van Peenen PF, Putrali J. Anopheles barbirostris (Van der Wulp) still an efficient vector of Brugia malayi in Central Sulawesi (Celebes), Indonesia. Trans R Soc Trop Med Hyg. 1976;70:259.

30. Lien JC, Kawengian BA, Partono F, Lami B, Cross JH. A brief survey of the mosquitoes of South Sulawesi, Indonesia, with special reference to the identity of Anopheles barbirostris (Diptera: Culicidae) from the Margolembo area. J Med Entomol. 1977;13:719-27.

31. Reid JA, Harrison BA, Atmosoedjono S. Variation and vector status in Anopheles barbirostris. Mosq Syst. 1979;11:235-51. 
32. Elyazar IR, Sinka ME, Gething PW, Tarmidzi SN, Surya A, Kusriastuti R, et al. The distribution and bionomics of Anopheles malaria vector mosquitoes in Indonesia. Adv Parasitol. 2013;83:173-266.

33. Gajapathy K, Jude PJ, Goodacre SL, Peiris LB, Ramasamy R, Surendran SN. Molecular characterization of the malaria vector Anopheles barbirostris van der Wulp in Sri Lanka. Parasit Vectors. 2014;7:348.

34. Alam MS, Khan MG, Chaudhury N, Deloer S, Nazib F, Bangali AM, et al. Prevalence of anopheline species and their Plasmodium infection status in epidemic-prone border areas of Bangladesh. Malar J. 2010;9:15.

35. Tri Baskoro TS. Cryptic species within Anopheles barbirostris Van der Wulp, 1884, inferred from nuclear and mitochondrial gene sequence variation. PhDThesis, Liverpool University, Liverpool, UK; 2001.

36. Suwannamit S, Baimai V, Otsuka Y, Saeung A, Thongsahuan S, Tuetun B, et al. Cytogenetic and molecular evidence for an additional new species within the taxon Anopheles barbirostris (Diptera: Culicidae) in Thailand. Parasitol Res. 2009;104:905-18.

37. Manguin S, Vas D. Towards malaria elimination: A leap forward. London, UK: IntechOpen; 2018. https://www.intechopen.com/books/towardsmalaria-elimination-a-leap-forward

38. Saeung A, Otsuka Y, Baimai V, Somboon P, Pitasawat B, Tuetun B, et al. Cytogenetic and molecular evidence for two species in the Anopheles barbirostris complex (Diptera: Culicidae) in Thailand. Parasitol Res. 2007;101:1337-44.

\section{Publisher's Note}

Springer Nature remains neutral with regard to jurisdictional claims in published maps and institutional affiliations.
Ready to submit your research? Choose BMC and benefit from:

- fast, convenient online submission

- thorough peer review by experienced researchers in your field

- rapid publication on acceptance

- support for research data, including large and complex data types

- gold Open Access which fosters wider collaboration and increased citations

- maximum visibility for your research: over 100M website views per year

At BMC, research is always in progress.

Learn more biomedcentral.com/submissions 